\title{
25 Research Square \\ The Fire Resistance Performance of Concrete Columns with Different Compressive Strength
}

\section{Rafid Saeed Atea ( $\square$ rafid1980@yahoo.com )}

University of Kufa

\section{Original Article}

Keywords: Concrete high performance, compressive strength, Reinforced Concrete Column, Finite Element Analysis (FEA), Simulation, Abaqus, Fire

Posted Date: November 15th, 2021

DOI: https://doi.org/10.21203/rs.3.rs-1051498/v1

License: (1) This work is licensed under a Creative Commons Attribution 4.0 International License. Read Full License 


\section{Abstract}

Four full concrete columns have been created Tested below high temperature for The fire resistance of concrete elements in concrete with particular compressive strengths. The standard concrete with compressive strength values of C25 were made of one of the four specimens, while the rest were made of C35, C60 and C75 respectively, respectively. During simulation of Within the laboratory furnace, the same For the specimens, axial forces were applied. Many experimental outcomes parameters were evaluated in contrast, including temperature changes, Vertical moving, side deflection, fire resistance and Failed properties of the specimen. The results have shown a rise in the compressive strength of the concrete for the concrete columns from the outside up to the inside of the column. Of columns of the the same cross section of the lower compressive forces of concrete display better fire resistance efficiency with the same initial axial strength ratio. The C35, C60 and C75 columns' fire resistance is higher than standard concrete columns. The initial and secant rigidity of the columns of Reinforced concrete ( $\mathrm{RC}$ ) has also The percentage decreased dramatically after fire exposure and the temperature increased from 25 to $750^{\circ} \mathrm{C}$.

\section{Introduction}

Many researchers have been studying the behavior of Reinforced Concrete $(R C)$ exposed to fire over the last two decades. Understanding the column behavior at high temperatures helps to assess the fire protection degree of the structure. The overall load for a column exposed to fire was indicated to be $20-40$

$\%$ Lower than the column before the fire [1]. A major decrease in the elasticity module was also observed at high temperatures which showed a 62-72 percent decreases after heating up to $400{ }^{\circ} \mathrm{C}$.

Several experiments have been carried out based Concrete part fire output. Lie et al. [2, 3] and other Canadian citizens in the 1990s researchers conducted studies with fire resistance, primarily on standard Filled RC columns and tubular steel columns with changed pieces of concrete, available their formula for fire resistance, now used by the global construction industry. In Kodur et al. [4, 5] and Iguchi et al. [6] regular concrete RC beams and columns were studied fire resistance. Gernay et al. [7] structural performance of natural fires in concrete columns was investigated.

The modern form of environmental-friendly material recycled aggregate concrete (RAC), using waste concrete to substitute natural aggregates for recycled materials, is rendered partly or completely by washing, grinding, grading and mixing methods. Sarhat et al. [8] examined RAC's residual mechanical response following hightemperature exposure. However, only when the RC column fire resistance efficiency with different intensities was investigated, few fire resistance experimental concert studies of RC structures and materials perforated. The principal structural elements of most buildings are vertical columns and the loss of load-bearing capacity in the fire causes the entire structure to be partially or entirely demolished. Work on the efficiency of RC columns to protect life and property in fire situations is thus important. The results show that specimens with a high column have a lower temperature than standard concrete, load power, strength and fire conditions in the same place. Fire endurance decreases as specimen strength increases.

In this paper, On the basis of experimental data, the efficiency of fire resistance was evaluated of three RC columns and one Standard RC columns of specific compressive concrete forces. in order to give an experimental basis for the use of the design of fire-resistance using different concrete compressive strengths.

Page 2/12 


\section{Resources And Goals}

The debate above indicates that ductility and energy absorption and column rigidity are important, because safety is guaranteed in these columns when natural disasters happen. The ductile behavior of the columns before and after the fire is more important during the fire as at the beginning of the column's vital sections it provides a visible warning, with no severe resistance loss, which in effect provides the building a time to safe evacuation and to ensure the protection of the fire-fighters. Until now, however, only relatively few studies have concentrated on Ductility study, energy absorption potential and column rigidity. Data showing the status of these characteristics after the fire has been released are also lacking.

This study aims to collect and raise knowledge in this area in order to address the gaps in science. The main objective of such work conducts investigational analysis to investigate Effect on ductility, energy efficiency and steepness characteristics of columns of RC exposed to fire and exposed to stress on two opposite sides.

\section{Materials And Manufacturing}

The optimum RC mixing proportion is shown in table (1), which was selected for the production of RC with specific compressive strength following multiple test mixes and ensuring workability for compliance with the ASTM C1437-15 requirement [9]. For this study [20], products that cast off included cement [18], sand, gravel [19], steel enhancement and traditional water processing with concrete admixtures (superplasticizer's) were used [20].

\subsection{Experimental Program of Structural Behavior}

Structural behavior study method consists of casting and testing 4 specimens. The columns of RC were Cast of different abilities. Each of 4 specimens (NC) with concrete mixtures has compressive cylinder strength of approximately 25, 35, 60 and $75 \mathrm{MPa}$ respectively. Tables (1), (2) and (3) demonstrate the mixing proportions, fresh properties and strength of these blends, and characteristics of the steel reinforcing bars. In other words, the key parameters in this analysis are concrete form and compressive power.

Table (1): Mix proportion of concrete.

\begin{tabular}{|lllllll|}
\hline $\begin{array}{l}\text { Concrete } \\
\text { type }\end{array}$ & $\begin{array}{l}\text { Mix } \\
\text { symbol }\end{array}$ & $\begin{array}{l}\text { Cement } \\
\left(\mathbf{k g} / \mathrm{m}^{3}\right)\end{array}$ & $\begin{array}{l}\text { Water } \\
\left(\mathrm{kg} / \mathrm{m}^{3}\right)\end{array}$ & $\begin{array}{l}\text { Sand } \\
\left(\mathrm{kg} / \mathrm{m}^{3}\right)\end{array}$ & $\begin{array}{l}\text { Gravel } \\
\left(\mathbf{k g} / \mathrm{m}^{3}\right)\end{array}$ & $\begin{array}{l}\text { SP/C } \\
\text { \%by } \\
\text { wt. }\end{array}$ \\
\hline $\mathrm{NC}$ & $\mathrm{NC25}$ & 350 & 181 & 700 & 1155 & - \\
\hline $\mathrm{NC35}$ & 420 & 181 & 700 & 1155 & - \\
\hline $\mathrm{NC60}$ & 465 & 175 & 675 & 1115 & 0.35 \\
& $\mathrm{NC75}$ & 570 & 159 & 660 & 1085 & 0.70 \\
\hline
\end{tabular}

Table(2)Results of Mechanical Properties of Hardened Tests 


\begin{tabular}{|lllll|}
\hline Column symbol & f'c MPa[21] & fr MPa[22] & ft MPa[23] & Ec GPa[24] \\
\hline RC25 & 25 & 3.68 & 2.65 & 15.54 \\
\hline RC35 & 35 & 5.145 & 3.71 & 20.79 \\
\hline RC60 & 60 & 8.91 & 6.43 & 35.54 \\
\hline RC75 & 75 & 11.08 & 7.87 & 43.79 \\
\hline
\end{tabular}

Table (3) Properties of bars of steel *

\begin{tabular}{|c|c|c|c|c|c|c|c|}
\hline $\begin{array}{l}\text { Diameter of } \\
\text { the nominal } \\
\text { bar }(\mathrm{mm})\end{array}$ & $\begin{array}{l}\text { Zone of } \\
\text { the Bar } \\
(\mathrm{mm} 2)\end{array}$ & $\begin{array}{l}\text { Modulus } \\
\text { of } \\
\text { Elasticity } \\
\text { (GPa) }\end{array}$ & $\begin{array}{l}\text { Yield } \\
\text { Stress } \\
\text { (MPa) }\end{array}$ & $\begin{array}{l}\text { Strain at } \\
\text { Yield Stress } \\
(\mathrm{mm} / \mathrm{mm})\end{array}$ & $\begin{array}{l}\text { Ultimate } \\
\text { Stress } \\
\text { (MPa) }\end{array}$ & $\begin{array}{l}\text { Strain at } \\
\text { Ultimate } \\
\text { Stress } \\
\text { (MPa) }\end{array}$ & $\begin{array}{l}\text { Elongation } \\
\text { (\%) }\end{array}$ \\
\hline 8 & 50.27 & 202 & 545 & 0.0027 & 660 & 0.18 & 15.5 \\
\hline 12 & 113.1 & 201 & 503 & 0.00252 & 615 & 0.13 & 14.5 \\
\hline \multicolumn{8}{|c|}{ * Ø8mm manufactured by Turkish company } \\
\hline \multicolumn{8}{|c|}{ * Ø12 manufactured by Ukraine company. } \\
\hline \multicolumn{8}{|c|}{ *Tests were carried out by testing laboratory in the College of Engineering. University of Kufa } \\
\hline
\end{tabular}

The mold was arranged from plywood with internal dimensions (100 to100 to 11000) $\mathrm{mm}$ in order to cast column samples and it was designed according to the ACI 318M-11[25] design code. Four longitudinal steel reinforcement bars were used at the cross section of each column specimen corner. The longitudinal steel support bar diameters have been used $(12 \mathrm{~mm})$. Even stirrups were deformed steel bars with $(8 \mathrm{~mm})$ diameter. The column strengthening details are shown in Figure (1).

\subsection{Testing procedures}

The fire experiments were performed by casting off a furnace made Refractive brick and refractive mother in size $(15000=1500 / 1250 \mu \mathrm{m})$ of $250 \mathrm{~mm}$ wall thickness. The combination comprises four liquefied petrol gas burners on each side of the fire to spread the fire equally over the column length.. (2). The gas control unit and the heating pads were connected to a wireless gas gage in order to monitor the gas discharge, to maintain a constant firing temperature at a target temperature set in the digital gage prior to starting the fire test. The furnaces are a metal steel structure made of three main components, a loading frame, a firing cage with insulation caps like figure. Furnace is constructed from metals and is a steel structure. (2), by means of a lever crane, the column manually positioned in the furnace. Fire exposed columns. After exposure to flames, columns were tested with a 500-ton hydraulic loading machine and accuracy of 0,5 tons in the Concrete testing laboratory, At a temperature rate of $2{ }^{\circ} \mathrm{C} / \mathrm{s}$ the temperature measured slowly increased until the target temperature was surpassed by fire-temperature. The test configuration and instrumentation details are shown in Fig. (3). 


\section{Results And Discussion \\ 4.1 Load-deflection results}

The displacement phenomenon under load is very important to calculate as the temperature rises to understand and assess the behavior of the fire exposed column. As can be seen in the figures, the displacement increases with an increase in temperature. The deflectometer dial measurements were used to monitor Axial and sideways specimen deformation. As shown in Figuration, the demec points were placed For axial and lateral deformation pressure readings and dial gages. (3). The load was applied at a load rate of $1 \mathrm{kN} / \mathrm{s}$ using a load sensor. For this work two dial gauges with a precision of $0.001 \mathrm{~mm}$ per deviation were used. Such dial gages The lateral deformation was placed on a column-type electro-hydraulic tester piston at Halfway along the central vertical lines of the column specimens as shown in figure. (4) to (6), respectively.

\section{Conclusions Based On The Results Of The Experiment:}

The findings can be taken from the results of the parametric research discussed in the present paper using both experimental analysis for columns subjected to axial loads.

1. The index of the ductility displacement is not useful in determining the impact of fire exposure on RC column ductility in which displacement ductility index values have not been significantly affected following fire exposure.

2. In assessing the situation of ductility of RC Fire exposure columns, measurement Capacity of energy absorption has been demonstrated.

Results of the test indicate that RC columns missing approximately (33-47\%) Potential for energy absorption after exposure to the fire at about $400^{\circ} \mathrm{C}$ and $(55-63 \%)$ after exposure to the fire at about $750^{\circ} \mathrm{C}$.

3. Results of the test indicate that lateral addition connections and the increase of Layer of concrete is not necessary to increase the RC columns' ability to absorb residual energy after fire exposure to $750^{\circ} \mathrm{C}$.

Although The energy absorption potential of RC columns with a wider concrete cover is significantly decreased at $400^{\circ} \mathrm{C}$.

4. Fire temperatures increased from 400 to $750^{\circ} \mathrm{C}$ decreased concrete pressure strength and improved Ductility, absorption of energy and RC column rigidity features.

5. After concrete cracking, the deformation of high-performance cement columns increases as the strength of the concrete is increased.

6. As the fire spreads, cracks spread and the cement is broken, followed by a large explosion with some local longitudinal reinforcement, particularly in high cemented columns.

7. The paper suggests a new method to calculate the degraded columns ductility index following fire exposure based on their energy consumption efficiency. 
8. The results from the exploration analysis indicate that Containing and original rigidity decreased dramatically after fire exposure, and that the fire temperature rose by a higher percentage when the temperature increased between 400 and $750^{\circ} \mathrm{C}$.

9. Additional work needs to be performed Research the after fire activity of RC columns with standard fire curves after fire exposure at temperature levels above $750^{\circ} \mathrm{C}$ because, due to limited column dimensions, the results The fire temperatures of this work are limited to up to $750^{\circ} \mathrm{C}$.

10. The pinnacle strength of the concrete columns significantly increases with the compressive strength of the concrete improving the ductility, energy absorption and rigidity of the RC columns.

11. Reduce the crack size as the compressive strength of the concrete increases.

12. The overall stress in RC columns depends on the compressive strength of the concrete and the elevated temperature of the fire from 400 to $750^{\circ} \mathrm{C}$.

13. The findings of the final factor analysis were very consistent with the results of the experiments, the higher columns of lateral strain supported by larger bar diameters and vertical displacement were similar to those of Smaller bar diameter reinforced columns.

\section{Declarations}

\section{Declaration of interests}

Q The authors declare that they have no known competing financial interests or personal relationships that could have appeared to influence the work reported in this paper.

Title page and Funding

1-Full name: Rafid Saeed Atea

2-Academic position or professional affiliations: Assistant Professor

3. Last Degree earned :(PhD/ Structural Engineering)

4.Nationality: Iraqi

5.Address: Iraq - Najaf .

6.Mobil number: 009647809392111

7. Email: rafid1980@yahoo.com

8. Name and address of affiliation: university of Kufa / College of Engineering

9. Name of supporting funds Organization: no funds

\section{References}


1. Mohamed Bikhiet, N. F. El-Shafey, and H. M. El-Hashimy"Behavior of reinforced concrete short columns exposed to fire," Alexandria Engineering Journal 2014; vol. 53, pp. 643-653, 9.

2. Lie, T. and Celikkol, B. (1991). - Method to calculate the fire resistance of circular reinforced concrete columns\|, ACI Materials Journal, Vol. 88, No. 1, pp. 84-91

3. Lie, T.; Irwin, R.J. (1993), Method to calculate the fire resistance of reinforced concrete columns with rectangular cross section. ACl Struct. J. 1993; 90, 52-60.

4. Kodur, K.R.; Dwaikat, M. (2014), Performance-based fire safety design of reinforced concrete beams. Journal of Fire Protection Engineering,2007; 17(4):293-320

DOI: $10.1177 / 1042391507077198$

5. Kodur, K.R.; Sultan, M.A. (2014), Effect of Strength and Fiber Reinforcement on Fire Resistance of HighStrength Concrete Columns.2003; Journal of Structural

Engineering 129(2) DOI: 10.1061/(ASCE)0733-9445(2003)129:2(253)

6. Iguchi, S.; Hirashima, T.; Matsudo, M.; Shinozuka, W.; Kaneshiro, R. (2013), Fire performance of mixed structures composed of reinforced concrete columns and steel beams- Part 2-Influence of concrete spalling and forced horizontal displacement on the fire resistance of R/C columns. Struct. Constr. Eng.2013; 78, 623631.

7. Gernay, ; Dimia, M.S. Structural behaviour of concrete columns under natural fires. (2014), Eng. Comput.2014; 30(6):854-872 ,DOI: 10.1108/EC-05-2012-0103

8. Sarhat, R.; Sherwood, E.G. Residual mechanical response of recycled aggregate concrete after exposure to elevated temperatures. J. Mater. Civ. Eng. 2013; 25, 1721-1730.

9. ASTM, Standard test method for flow of hydraulic cement mortar (2015). http://dx.org/10.1520/C1437-15.

10. IraqiStandardsNo.5/1984,-OrdinaryPortlandcement|| Ministry of Housing and Construction, Baghdad, 2004

11. IraqiStandards45/1984,_-Aggregate from Natural Sources for Concrete and Construction\|, Ministry of Housing and Construction, Baghdad, 2004.

12. ASTM C494-04, —Standard Specification for Chemical Admixtures for Concretell, Annual Book of ASTM Standards, American Society for Testing and Materials, Vol. 04-02, 2007,

pp.1-9.

13. ASTM C39/C39M-2003, - Standard Test Method for Compressive Strength of Cylindrical Concrete Specimens\|, Vol. 4.2, 2003, pp. 1-5 and B.S. 1881: Part 116: 1983, —Methods for Determination of Compressive Strength of Concrete Cubes\|, January 1983, 1-8. [22]ASTM C78-02, -Standard Test Method for Flexural Strength of Concrete (Using Simple Beam with Third-point Loading)\|, Vol. 4.2, (2002), pp. 1-3.

14. ASTMC496/C496M-04, - Standard Test Method for Splitting Tensile Strength of Cylindrical Concrete Specimens\|, 4.2, (2004), pp. 1-5. 
15. ASTM C469-02, - Standard Test Method for Static Modulus of Elasticity and Poisson's Ratio of Concrete in Compression\|, Vol. 4.2, (2002), pp. 1-5

16. ACl 318M-11, —Building Code Requirements for Structure Concrete and Commentary\|l,

Figures
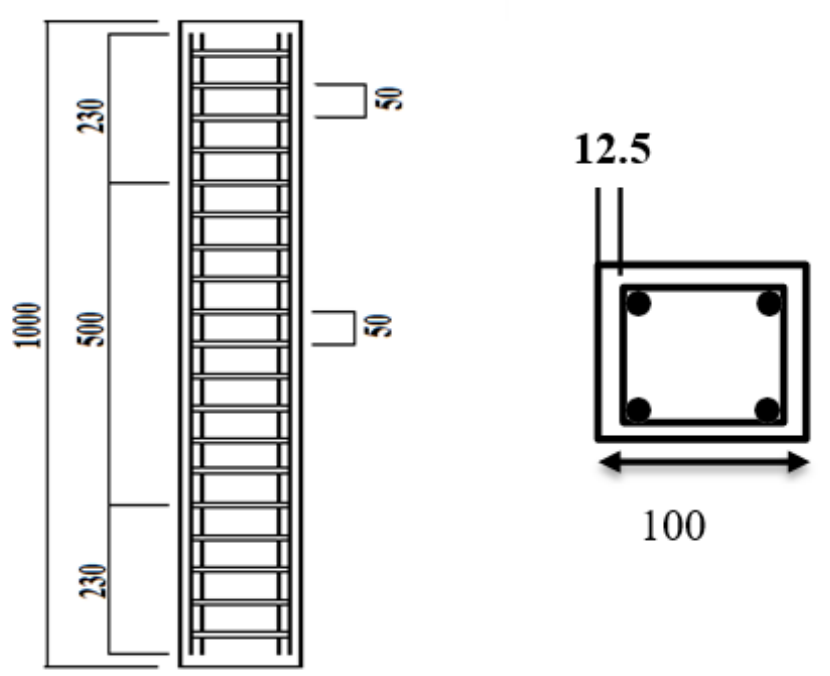

(b) Column with ties spacing $50 \mathrm{~mm}$

All dimensions are in mm

Figure 1

Details of columns reinforcement.

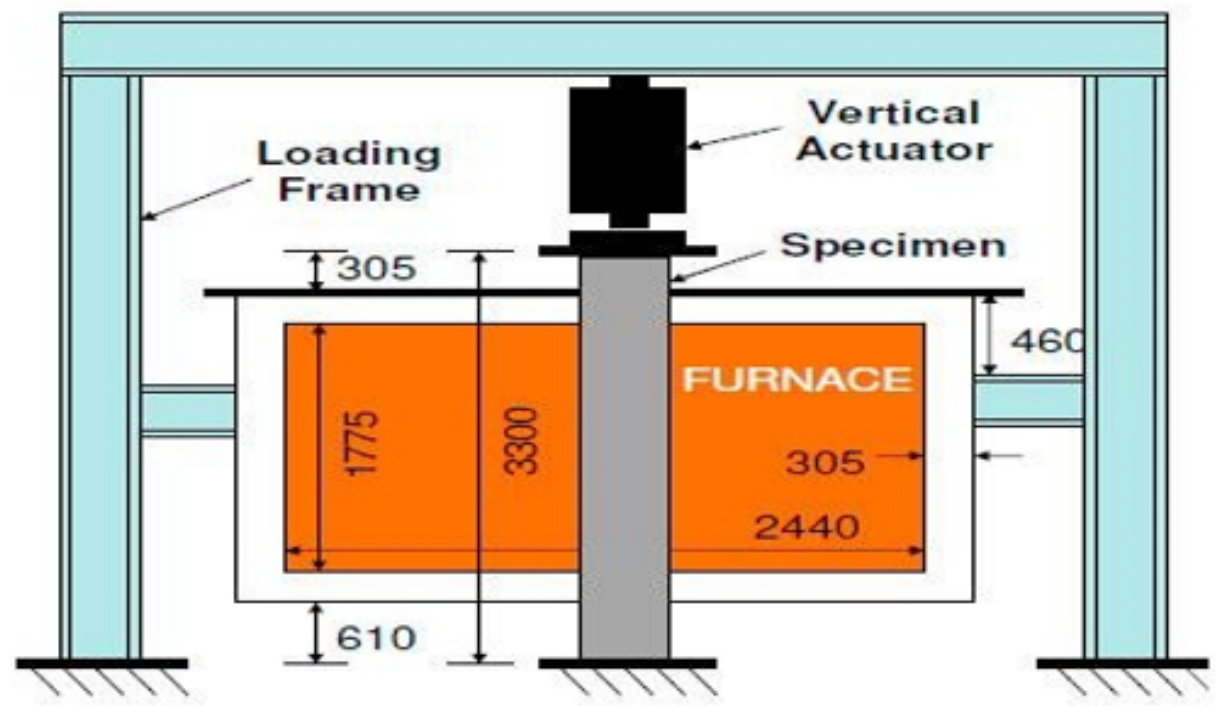


Figure 2

Fire test setup (dimensions in $\mathrm{mm}$ )

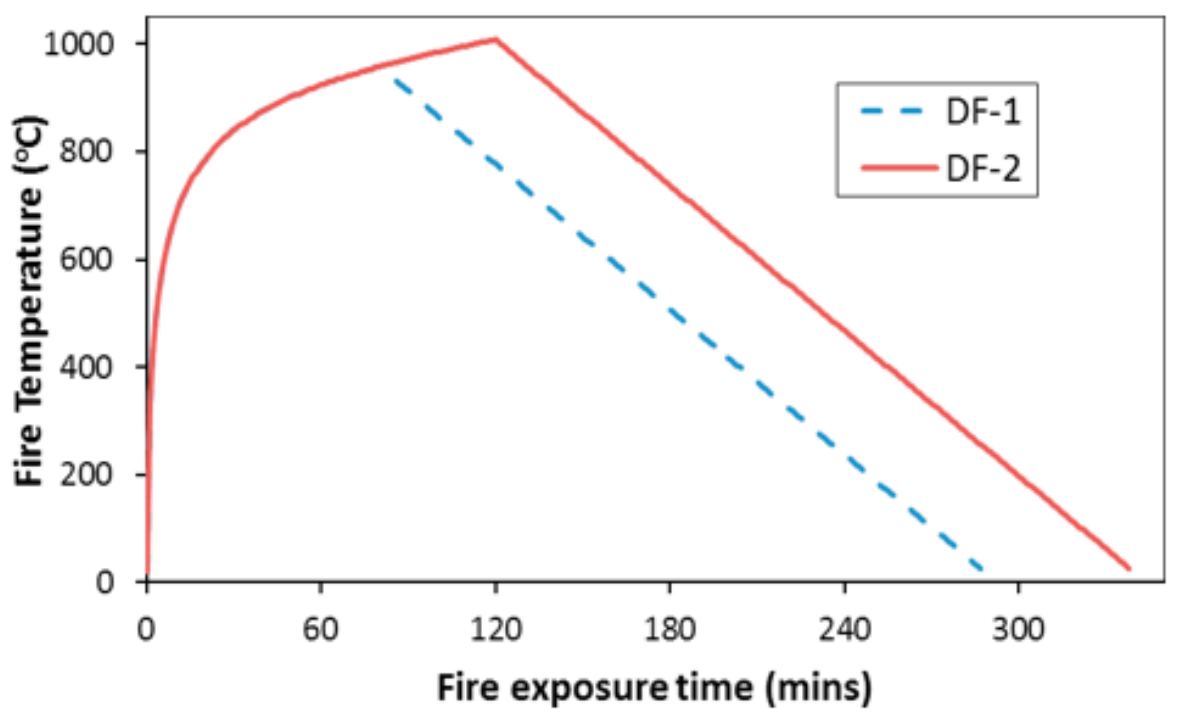

Figure 3

Design fire scenarios.

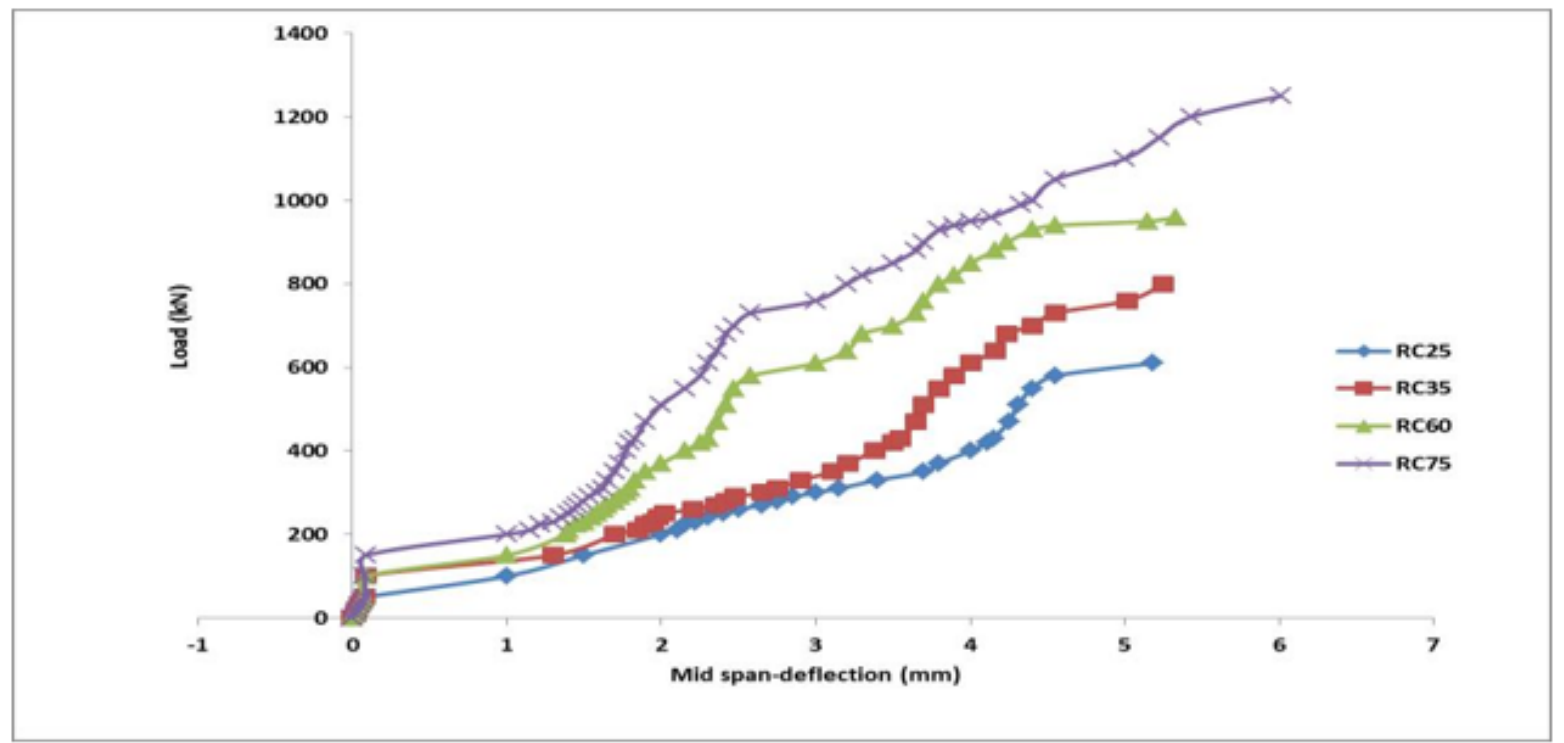

Figure 4

Relation load-deflection for columns temperature $25^{\circ} \mathrm{C}$. 


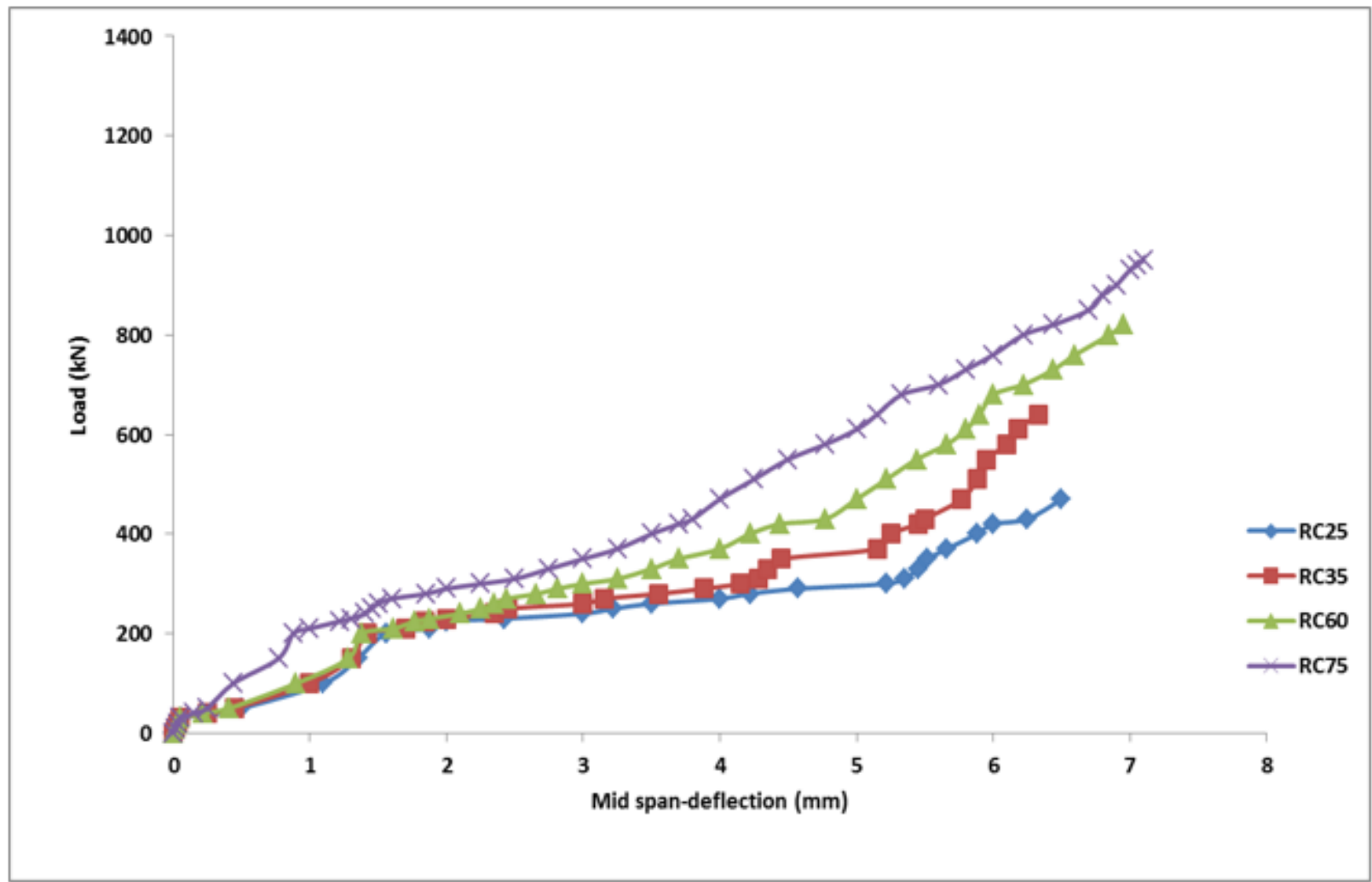

Figure 5

Relation load-deflection for columns temperature $400^{\circ} \mathrm{C}$. 


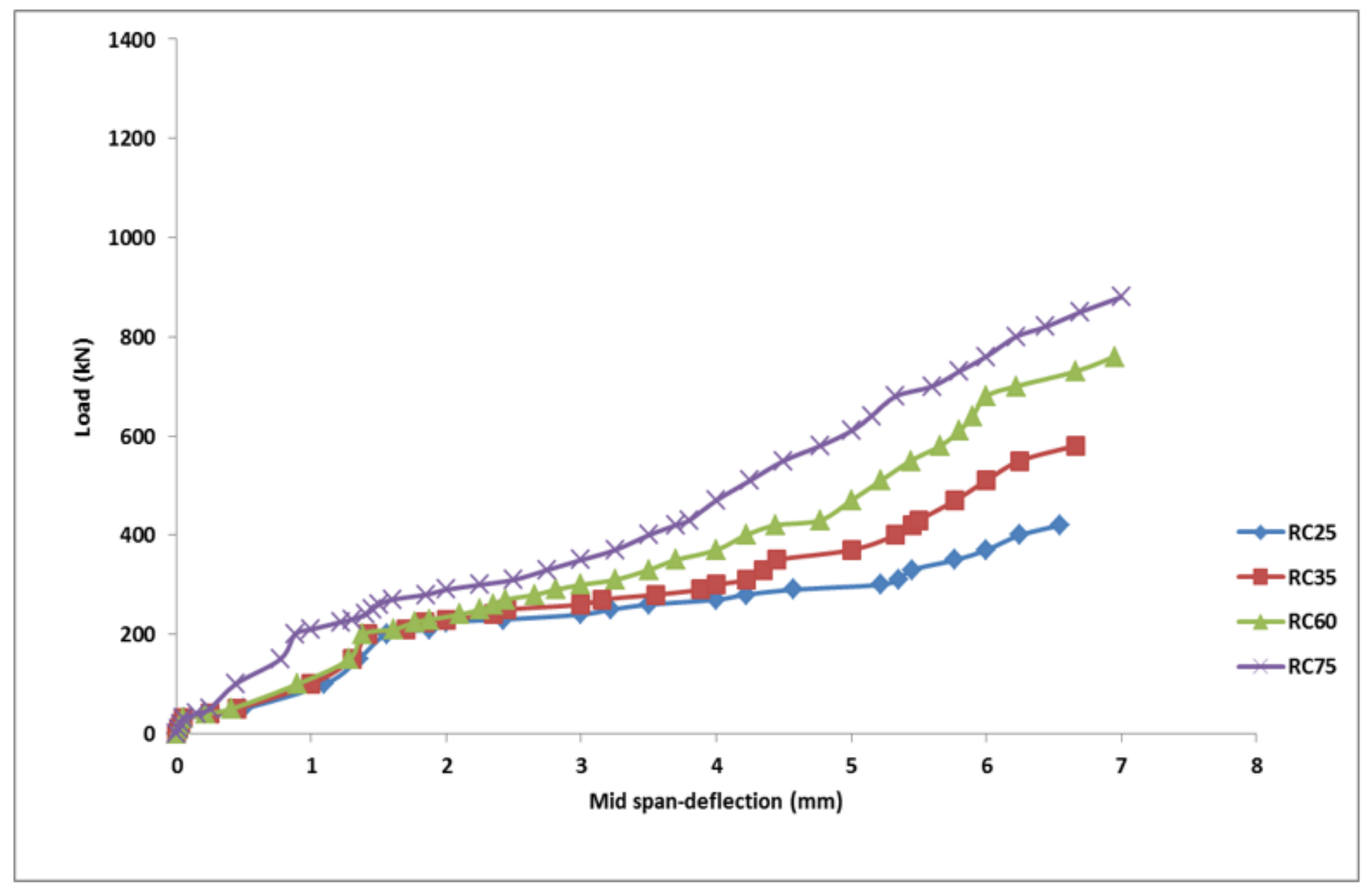

Figure 6

Relation load-deflection for columns temperature $600^{\circ} \mathrm{C}$. 


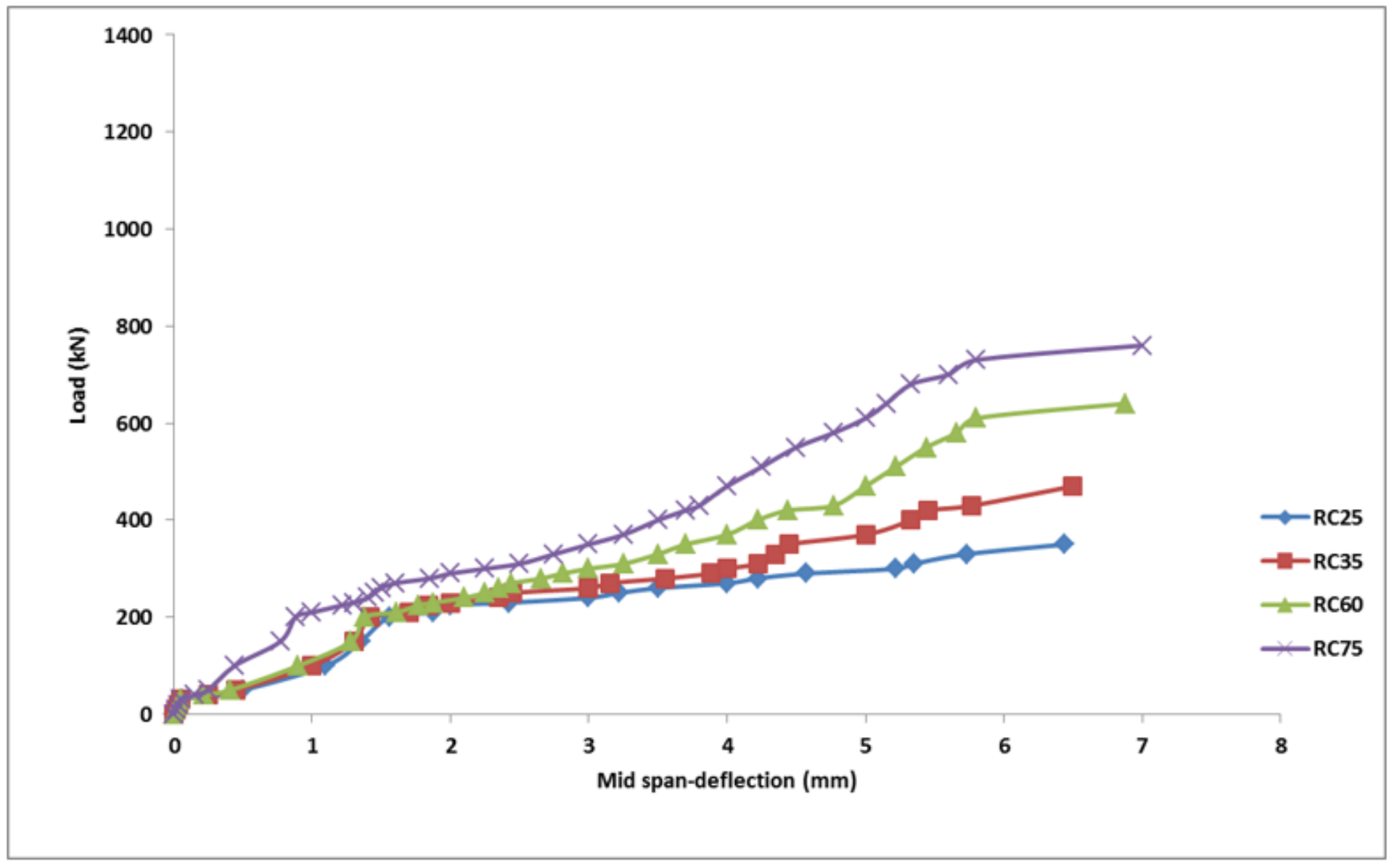

Figure 7

Relation load-deflection for columns temperature $750^{\circ} \mathrm{C}$. 